\title{
Coating of Pd and Co on Mordenite for a Catalyst of Hydrotreating of Cashew Nut Shell Liquid into Biofuel
}

\author{
Maya Tri Hapsari, Wega Trisunaryanti*, Iip Izul Falah, and Media Laila Permata \\ Department of Chemistry, Faculty of Mathematics and Natural Sciences, Universitas Gadjah Mada, \\ Sekip Utara, Yogyakarta 55281, Indonesia
}

* Corresponding author:

tel: $+62-811256055$

email:wegats@ugm.ac.id

Received: August 8, 2019

Accepted: January 29, 2020

DOI: $10.22146 /$ ijc. 48633

\begin{abstract}
The catalytic activity of Co and Pd loaded on mordenite (MOR) was evaluated in the hydrotreatment of cashew nut shell liquid (CNSL) into biofuel. Metals were loaded into MOR as support via wet impregnation process. The Co content was varied as 2, 4, and 6 wt.\% to produce Co(1)/MOR, Co(2)/MOR, Co(3)/MOR catalysts. The micromesoporous structures of the catalyst were confirmed by XRD, SEM, TEM, FTIR, and $\mathrm{N}_{2}$ adsorption-desorption measurement. AAS were used to analyze the amount of metal that is successfully loaded in the catalysts. Hydrotreating of the CNSL was conducted in a semibatch reactor at $450{ }^{\circ} \mathrm{C}$ with hydrogen flow $(20 \mathrm{~mL} / \mathrm{min})$ for $2 \mathrm{~h}$. The liquid product was analyzed using GC-MS. The activity of Co/MOR was compared with the activity of $P d / M O R$ as a noble metal. The result of the hydrotreatment process showed a decrease of liquid product in the sequence of $\mathrm{Co}(3) / M O R>\mathrm{Co}(2) / M O R>P d / M O R>C o(1) / M O R>$ $M O R$. The Co(3)/MOR catalyst exhibited the highest conversion of liquid hydrocarbon than the others (61.8 wt.\%), comprising predominantly by gasoline compounds with over $25.21 w t . \%$ conversion.
\end{abstract}

Keywords: cobalt; CNSL; mordenite; palladium

\section{- INTRODUCTION}

Fossil fuels are a major energy source widely used in various countries. However, depletion of petroleum is now deeply concerned and heavy consumption will cause environmental pollution. Thus, there is an urgent need to find suitable alternate fuels [1]. Nowadays, the world is confronted with two major problems, such as the limited supply of fossil fuels and its increasing demand with the growth of the population over the years. The gas emitted from the use of petroleum fuels, also contributes to environmental air pollution and global warming. These issues have led to the continuous search of a new clean and renewable energy source as an alternative [2]. One of the most attractive energy alternatives that have been studied these days is the use of biomass converted from renewable sources.

The cashew plant (Anacardium occidentale L.) is one commodity that has high economic value [3] and one of the largest plantations in Indonesia with over 547,000 ha [4]. The main product of the cashew plant is nuts. During the production of cashew nuts, its shell is usually disposed of as waste for it has no economic value. Previous research reported that cashew nut shell contains a high percentage of oils (50\%) called CNSL [5], making it a potential source to be used as a fuel alternative. The use of this oil as fuel has the benefit of its renewability, and it's utility as non-edible oil does not cause any competition with food production. However, the character of cashew nut shell oil that has a high viscosity, high density, and low volatility is inefficient to be directly used as biofuel [6].

Various methods have been developed to convert CNSL into a more suitable compound as fuel. Previous studies focused more on converting CNSL into biodiesel via transesterification. This process requires a considerable amount of chemical ingredients including base as a homogenous catalyst which is difficult to separate. Therefore, we develop a new idea to convert CNSL directly into hydrocarbon compounds through a hydrotreatment process. In this method, we utilize 
mordenite as a heterogeneous catalyst which is easier to separate. This method requires fewer chemical ingredients exhibiting more benefits to environmental conservation. In addition, the production of hydrocarbon compounds as a fuel is more desirable than biodiesel that contained FAME (Fatty Acid Methyl Ester) due to high energy density.

Mordenite is a well-known zeolite used in many catalytic reactions such as cracking, hydrotreatment, isomerization, etc. [7]. It is one of the six most abundant zeolites with high silica content which contributes to its high thermal stability. However, the major drawback of mordenite lies in its limited channel and pore size, which is limiting its activity, selectivity and stability [8-9]. One way to improve the activity of mordenite is by adding metal, either on its surface or in its pore, to give a more active site to the catalyst. Previously scientific reports were published concerning on the influence of metal on the activity of the mordenite catalyst. The previous research has proven that the presence of metal has a positive effect in the hydrogenation process, exhibiting higher selectivity [10].

The use of transition metal, such as nickel, in the hydrotreatment process, has been continuously studied as a replacement of noble metals ( $\mathrm{Pt}$ and $\mathrm{Pd}$ ) due to its high availability and activity. However, the low selectivity of nickel and its tendency to deposit coke have urged a modification to be proposed. Commonly, to improve its activity and selectivity for hydrotreating, Nickel is paired with Molybdenum in the bimetallic system (NiMo). Hydrotreating CNSL oil using bimetallic NiMo loaded in ZAA was done previously producing over $58.32 \%$ of hydrocarbon compounds [11]. The use of NiMo requires two types of metals will need a higher cost to synthesize. Therefore, in this study, Cobalt is employed to replace Nickel. Cobalt has a more unpaired electron in $\mathrm{d}$ orbital which can be used as a site for hydrogen splitting in hydrocracking reaction. Due to these unpaired electrons, it is expected that higher activity during the hydrogenation of CNSL will be obtained. In previous research [12], hydrocracking of a-cellulose using $\mathrm{Co} / \mathrm{MOR}$ catalyst obtained liquid product of $90.48 \mathrm{wt} . \%$ at $450{ }^{\circ} \mathrm{C}$. However, the effect of metal concentration loaded in the pore of mordenite has not been discussed before. In this study, the activity of $\mathrm{Co} / \mathrm{MOR}$ and the effect of metal concentration in hydrotreatment of CNSL oil will be evaluated. The result will also be compared with the liquid product obtained from the hydrotreatment using noble metals like Pd to evaluate significant differences of activity by both metals at its respective concentration.

\section{EXPERIMENTAL SECTION}

\section{Materials}

Zeolite mordenite (HSZ 640-HOA) was purchased from Catalyst \& Chemical Ind.Co.Ltd., $\mathrm{PdCl}_{2}$ (with 59\% $\mathrm{Pd}), \mathrm{Co}\left(\mathrm{NO}_{3}\right)_{2} \cdot 6 \mathrm{H}_{2} \mathrm{O}$ were purchased from Merck, methanol 98\% were purchased from Sigma-Aldrich, Cashew Nut Shell Liquid (CNSL) was collected from Karang Tengah Village, Bantul, Yogyakarta.

\section{Instrumentation}

The functional groups of MOR and catalysts were determined using Fourier Transform Infrared spectrometer (FTIR, Shimadzu Prestige-21) equipped with data station in the range of $400-4000 \mathrm{~cm}^{-1}$ with a $\mathrm{KBr}$ disc technique. X-Ray Diffraction (XRD, Philips X'Pert MPD) was used to observe the crystallinity of the catalysts. The pore images were taken using a Transmission Electron Microscope (TEM, JEM-1400). The surface parameters (surface area, pore volume, and pore diameter) of the sample were analyzed using Surface Area Analyzer (SAA, Quantachrome NOVAyouch 4LX), the surface area was calculated by the Brunaeur-Emmett-Teller (BET) method, and the pore size distribution was calculated by the BarretJoyner-Halenda (BJH) method. The amount of metals content of all samples was determined using Atomic Absorption Spectrophotometer (AAS, PERKIN ELMER 5110 PC). The surface morphology of catalyst was analyzed using Scanning Electron Microscopy (SEM, JEOL SM-6510). The liquid products obtained from the hydrotreating of CNSL were analyzed using gas chromatography-mass spectrometry (GC-MS, Shimadzu QP2010S). 


\section{Procedure}

\section{Catalysts preparation and characterization}

The Co/MOR and Pd/MOR catalysts were prepared by impregnation method [22]. Metals (Co and Pd) were loaded into $\mathrm{MOR}$ by wet impregnation using a salt precursor of $\mathrm{Co}\left(\mathrm{NO}_{3}\right)_{2} \cdot 6 \mathrm{H}_{2} \mathrm{O}$ and $\mathrm{PdCl}_{2}$.

An amount of $6.6 \mathrm{mg} \mathrm{P_{Cl }}$ was dissolved in $50 \mathrm{~mL}$ methanol and the solution was then mixed with $2 \mathrm{~g}$ of MOR and stirred for another $7 \mathrm{~h}$.

The Co concentration was varied in 2, 4, and 6 wt.\% towards the MOR using the $\mathrm{Co}\left(\mathrm{NO}_{3}\right)_{2} \cdot 6 \mathrm{H}_{2} \mathrm{O}$ and diluted in $50 \mathrm{~mL}$ of methanol, then stirred for $7 \mathrm{~h}$ to produce $\mathrm{Co}(1) / \mathrm{MOR}, \mathrm{Co}(2) / \mathrm{MOR}$ and $\mathrm{Co}(3) / \mathrm{MOR}$ respectively. The solutions were evaporated at $70{ }^{\circ} \mathrm{C}$, then calcined with $\mathrm{N}_{2}$ flow for $3 \mathrm{~h}$ at $450{ }^{\circ} \mathrm{C}$. Finally, the Pd/MOR and Co/MOR catalysts were produced by reduction with $\mathrm{H}_{2}$ flow for $3 \mathrm{~h}$ at $450^{\circ} \mathrm{C}$.

\section{Hydrotreating of CNSL}

The CNSL and catalyst in a weight ratio of 50:1 were loaded in a semi-batch reactor. In this study, $0.1 \mathrm{~g}$ of catalyst was used to convert $5 \mathrm{~g}$ of CNSL oil into biofuel. The reaction temperature was $450{ }^{\circ} \mathrm{C}$ for $2 \mathrm{~h}$ with $20 \mathrm{~mL} / \mathrm{min}$ of hydrogen flow. The reactor was connected with a condenser and the liquid product was collected and identified by GCMS analysis.

\section{- RESULTS AND DISCUSSION}

\section{Catalysts Characterization}

The X-ray diffractogram of MOR, Co/MOR, and $\mathrm{Pd} / \mathrm{MOR}$ were shown in Fig. 1. The peaks found in $\mathrm{Co}(1) / \mathrm{MOR}, \mathrm{Co}(2) / \mathrm{MOR}, \mathrm{Co}(3) / \mathrm{MOR}$ and $\mathrm{Pd} / \mathrm{MOR}$ were proved to be similar to those found in MOR. Each catalyst exhibited sharp peaks at Bragg angle 9.7, 13.5, and $22.3^{\circ}$. However, the intensity of each peak was shown to be slightly decreased after the impregnation of Co 2, 4, and 6 wt.\%, indicating the decrease of crystallinity of MOR structure [13]. On the other hand, several peaks intensity increased for Pd/MOR catalyst, suggesting the loading of a small amount Pd ( $0.5 \mathrm{wt} . \%$ towards the MOR) did not cause blockage in the pores nor damage the crystalline sites of MOR. Instead, Pd appeared to donate its crystalline phase which contributes to the increase of crystallinity in the Pd/MOR catalyst. Fig. 1 also revealed that the metals did not give any additional peak to the XRD pattern, which suggests the presence of small metal particles with high dispersion and low crystallinity [14].

The FTIR spectrum of the MOR and catalysts were investigated to investigate the effect of metal loaded on $\mathrm{TO}_{4}$ sites. FTIR spectra of $\mathrm{Co} / \mathrm{MOR}$ with various metal concentrations were shown in Fig. 2. Before impregnation, FTIR spectra of MOR revealed vibration band at 1080 and $3749 \mathrm{~cm}^{-1}$ which correspond to the asymmetric stretching vibration of $\mathrm{T}-\mathrm{O}$ (where $\mathrm{T}=\mathrm{Si}$ or $\mathrm{Al}$ ) and the stretching of $\mathrm{O}-\mathrm{H}$ hydroxyl group, respectively [15-16]. The band appeared at 640 and $462 \mathrm{~cm}^{-1}$ respectively refer to symmetric stretching and bending vibration of $\mathrm{T}-\mathrm{O}$. The metal addition caused the band to appear at $1635 \mathrm{~cm}^{-1}$ due to the increase of the Brønsted acid site. Fig. 2(a) and 2(d) showed FTIR spectra of MOR before and after the impregnation of $\mathrm{Pd}$. Overall, FTIR spectra between Pd/MOR and Co/MOR do not have differences. As the vibration bands revealed to similar, metal impregnation does not cause any alteration to the functional group in MOR structure. This result is in accordance with XRD characterization.

The textural properties of the catalyst were shown in Table 1. After the metals were loaded, the pore volume, as well as the surface area, are shown to significantly

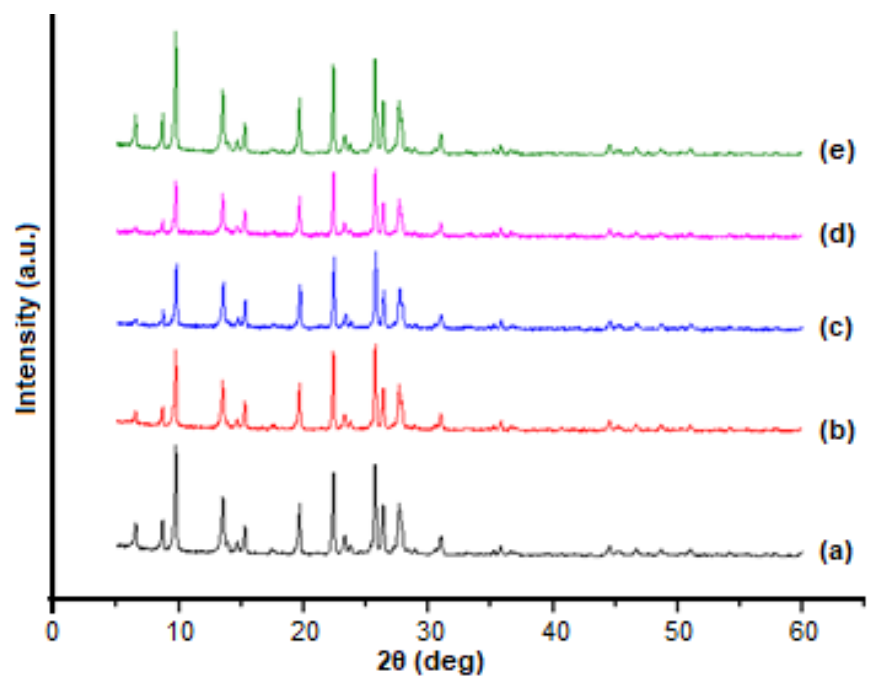

Fig 1. XRD pattern of the catalysts: (a) mordenite, (b) $\mathrm{Co}(1) / \mathrm{MOR}$, (c) $\mathrm{Co}(2) / \mathrm{MOR}$, (d) $\mathrm{Co}(3) / \mathrm{MOR}$, and (e) $\mathrm{Pd} / \mathrm{MOR}$ 


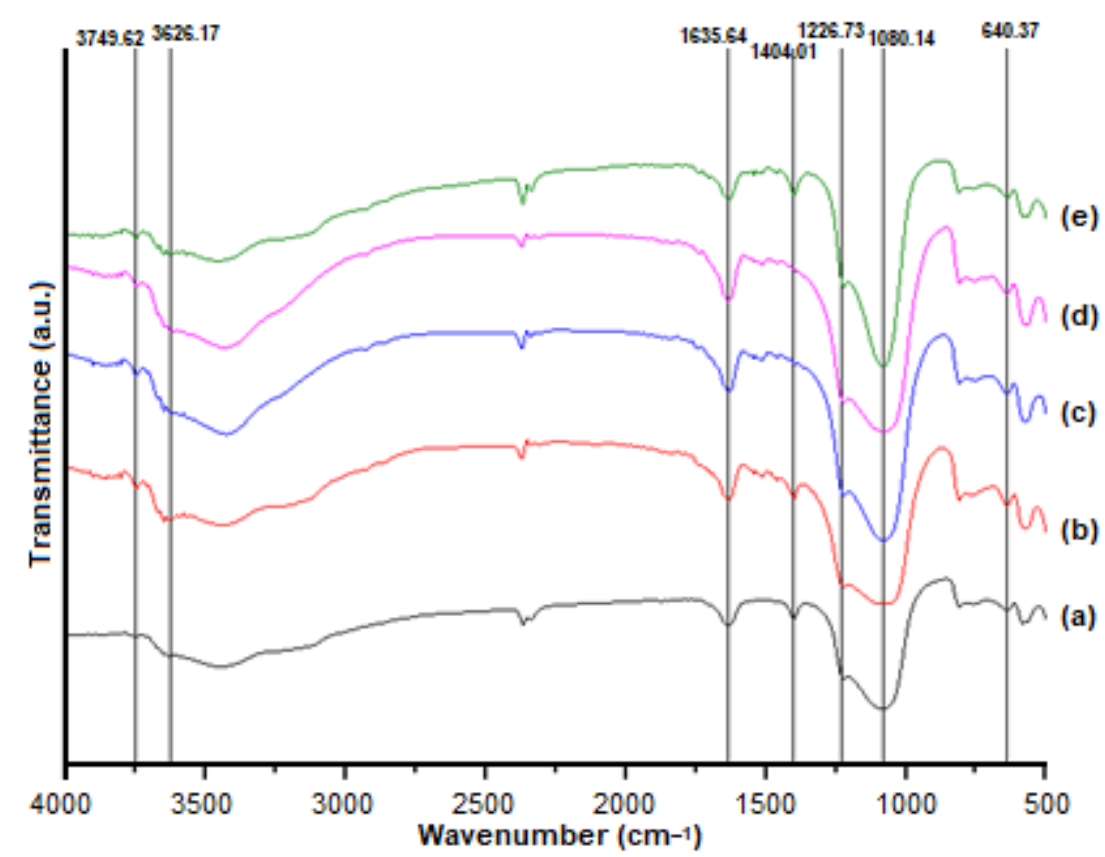

Fig 2. FTIR spectra of: (a) MOR, (b) $\mathrm{Co}(1) / \mathrm{MOR}$, (c) $\mathrm{Co}(2) / \mathrm{MOR}$, (d) $\mathrm{Co}(3) / \mathrm{MOR}$ and (e) Pd/MOR

Table 1. Summary of textural properties of catalyst

\begin{tabular}{lcccccc}
\hline Sample & $\begin{array}{c}\text { Surface area } \\
\left(\mathrm{m}^{2} / \mathrm{g}\right)\end{array}$ & $\begin{array}{c}\text { Pore volume } \\
(\mathrm{cc} / \mathrm{g})\end{array}$ & $\begin{array}{c}\text { Pore diameter } \\
(\mathrm{nm})\end{array}$ & $\begin{array}{c}\text { Total pore } \\
\text { volume }(\mathrm{cc} / \mathrm{g})\end{array}$ & $\begin{array}{c}\text { Metal } \\
\text { loading }\end{array}$ & $\begin{array}{c}\text { Acidity } \\
(\mathrm{mmol} / \mathrm{g})\end{array}$ \\
\hline $\mathrm{MOR}$ & 280.38 & 0.02 & 3.56 & 0.17 & - & 5.87 \\
$\mathrm{Co}(1) / \mathrm{MOR}$ & 592.62 & 0.27 & 3.20 & 0.52 & 1.11 & 8.80 \\
$\mathrm{Co}(2) / \mathrm{MOR}$ & 233.75 & 0.02 & 3.22 & 0.14 & 2.46 & 12.06 \\
$\mathrm{Co}(3) / \mathrm{MOR}$ & 192.90 & 0.01 & 3.21 & 0.11 & 4.14 & 15.67 \\
$\mathrm{Pd} / \mathrm{MOR}$ & 407.62 & 0.02 & 3.23 & 0.23 & 0.41 & 11.29 \\
\hline
\end{tabular}

decrease for $\mathrm{Co}(2) / \mathrm{MOR}$ and $\mathrm{Co}(3) / \mathrm{MOR}$ catalysts. The decrease was caused by the metal aggregations deposited in the pores leading to a blockage [17-19]. Meanwhile, the impregnation of $1 \% \mathrm{Co}$ and $\mathrm{Pd}$ for $\mathrm{Co}(1) / \mathrm{MOR}$ as well as $\mathrm{Pd} / \mathrm{MOR}$ exhibited a different behavior where they seemed to increase the pore volume and the surface area of MOR instead. This result suggests that due to the low quantity of metals in both catalysts, an aggregation that leads to blockage was barely formed. Instead, the smallsized metal particles are generated and distributed fairly distributed on the surface of MOR, contributing to its roughness which increases the surface area [20-21]. Total pore volumes of $\mathrm{Co} / \mathrm{MOR}$ catalysts are significantly decreased with more metal addition. The pore diameter of catalysts was shown to remain unchanged before and after impregnation.
Fig. 3 showed the pore distribution of the catalysts. The pore distribution ranges from $3-18 \mathrm{~nm}$, which again confirms the mesoporous characteristic of each catalyst [22]. The quantities of some pores with various diameters were shown to decrease after metal impregnation, which suggests the occurrence of pore blockage by metal aggregation as previously discussed [23].

The surface of the catalyst was captured in SEM images (Fig. 4). Although no major morphological difference was observed after the impregnation of metal, EDX analysis was able to detect the addition of a new metal particle as shown in Table 2. The Co appeared in EDX becomes more prominent with the increase of metal concentration loaded inside the pore of MOR as there would be more metal particles giving off its X-Ray light during the analysis process. Pd was also shown to 
appear in the EDX analysis for the Pd/MOR catalyst, which confirms the success of the impregnation process.

The Si/Al ratio of MOR that was quantitatively determined using AAS revealed to be 1.46 (mole/mole). AAS analysis was also used to determine the concentration of metal presence in each catalyst prepared as listed in Table 1. The concentration of cobalt loaded in the pore of $\mathrm{Co}(1) / \mathrm{MOR}, \mathrm{Co}(2) / \mathrm{MOR}$ and $\mathrm{Co}(3) / \mathrm{MOR}$ catalysts were found to be $1.11,2.46$, and $4.14 \mathrm{wt} . \%$, respectively. Meanwhile, $\mathrm{Pd} / \mathrm{MOR}$ catalyst revealed to contain $0.42 \mathrm{wt}$.\% of Pd metal. The amount of metal being successfully loaded was found to slightly differ from the intended. This suggested that not all Co and Pd metals added were fully impregnated into the pore of MOR due to the interaction between metal cations and an aqueous solvent. Therefore, the interaction between salts and MOR as support was slightly hindered.
The acidity test was done gravimetrically by exposing each catalyst material with the flow ammonia gas [18]. The results were stated in Table. 1. The addition

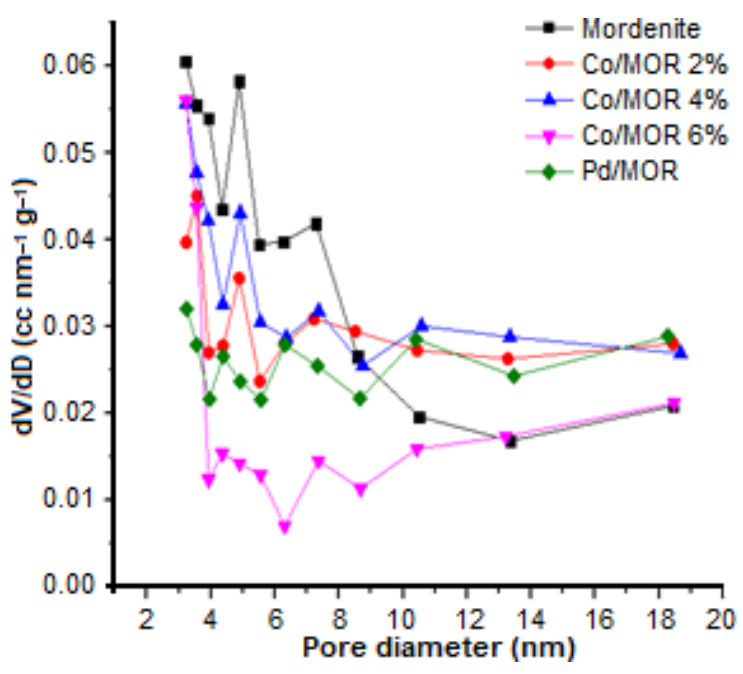

Fig 3. Pore distribution of catalyst

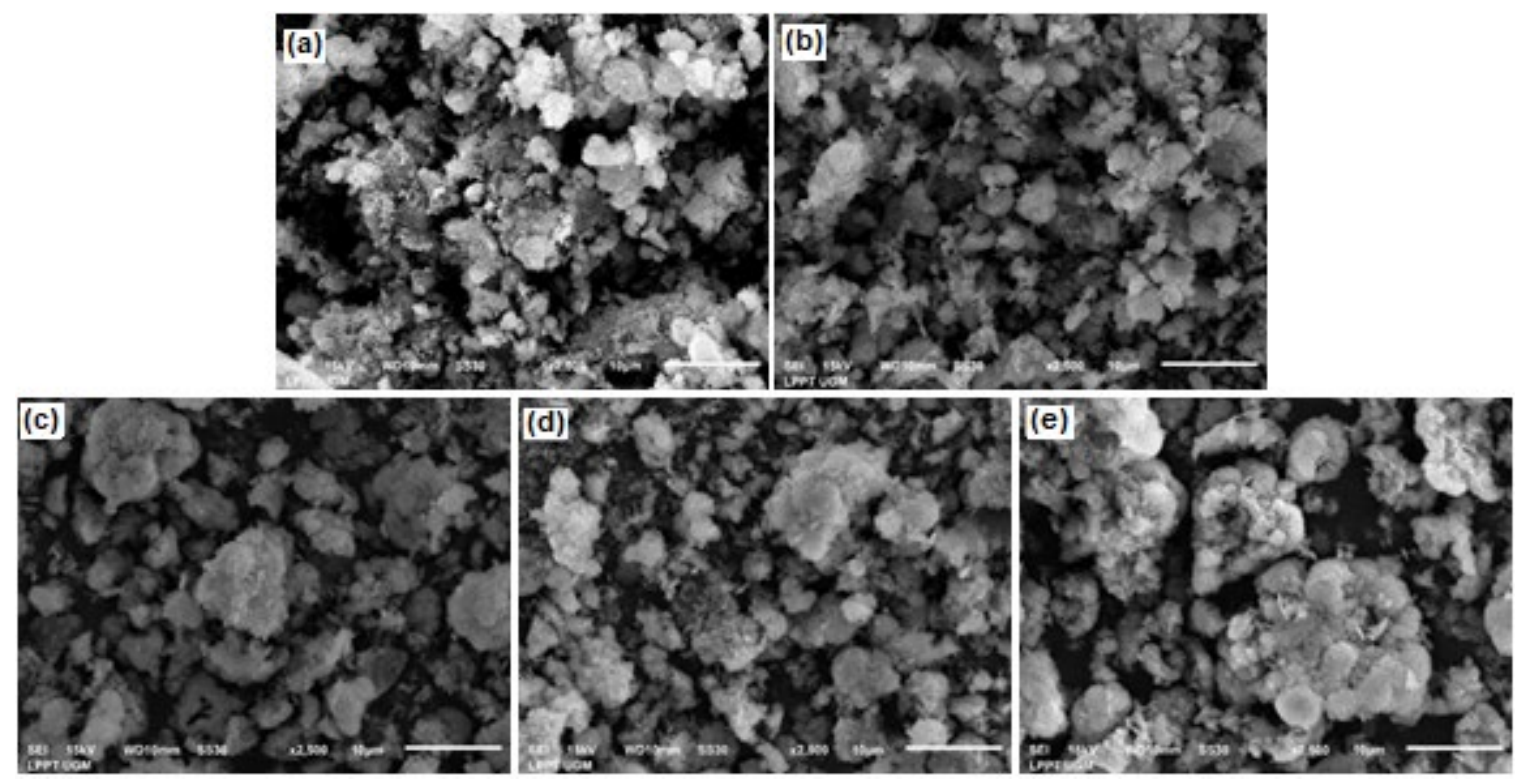

Fig 4. SEM images of (a) mordenite, (b) $\mathrm{Co}(1) / \mathrm{MOR}$, (c) $\mathrm{Co}(2) / \mathrm{MOR},(\mathrm{d}) \mathrm{Co}(3) / \mathrm{MOR}$, (e) Pd/MOR

Table 2. Chemical composition of catalysts based on EDX analysis

\begin{tabular}{llllll}
\hline \multirow{2}{*}{ Element } & \multicolumn{5}{c}{ Mass (\%) } \\
\cline { 2 - 6 } & $\mathrm{O}$ & $\mathrm{Si}$ & $\mathrm{Al}$ & $\mathrm{Co}$ & $\mathrm{Pd}$ \\
\hline $\mathrm{MOR}$ & 56.04 & 39.53 & 4.42 & - & - \\
$\mathrm{Co}(1) / \mathrm{MOR}$ & 47.5 & 46.52 & 4.96 & 1.01 & - \\
$\mathrm{Co}(2) / \mathrm{MOR}$ & 58.94 & 35.22 & 4.06 & 1.78 & - \\
$\mathrm{Co}(3) / \mathrm{MOR}$ & 51.76 & 38.05 & 4.24 & 5.95 & - \\
$\mathrm{Pd} / \mathrm{MOR}$ & 58.27 & 37.21 & 4.25 & - & 0.17 \\
\hline
\end{tabular}

Maya Tri Hapsari et al. 


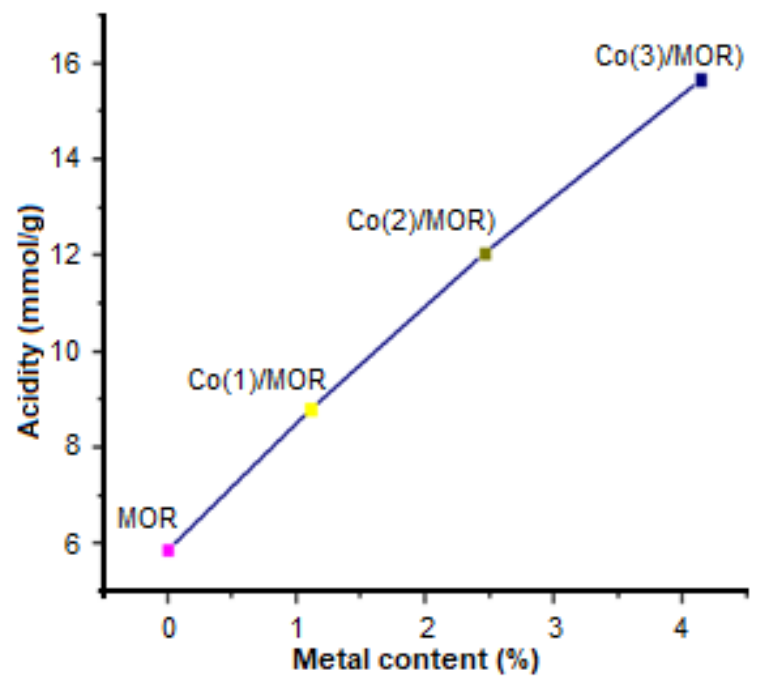

Fig 5. Correlation curve of acidity versus metal content of $\mathrm{Co} / \mathrm{MOR}$ catalysts

of Co and Pd on the MOR was shown to increase the catalyst acidity. This is related to the empty orbital presence in both Co and Pd metals which contributes as Lewis acid site, therefore increase the total amount of ammonia absorption. Table 1 shows that acidity level of the catalyst decreased with the trend of $\mathrm{Co}(3) / \mathrm{MOR}$ $(15.67 \mathrm{mmol} / \mathrm{g})>\mathrm{Co}(2) / \mathrm{MOR}(12.07 \mathrm{mmol} / \mathrm{g})>\mathrm{Pd} / \mathrm{MOR}$ $(11.29 \mathrm{mmol} / \mathrm{g})>\mathrm{Co}(1) / \mathrm{MOR}(8.80 \mathrm{mmol} / \mathrm{g})>$ the $\mathrm{MOR}$ $(5.87 \mathrm{mmol} / \mathrm{g})$. The linear correlation between acidity and metal content was depicted by a graph as shown in Fig. 5, where total acidity increased significantly with higher metal concentration.

TEM images of MOR, $\mathrm{Co}(3) / \mathrm{MOR}$ and $\mathrm{Pd} / \mathrm{MOR}$ are shown in Fig. 6. Two regions were captured by TEM in MOR material. The dark spots region refers to the pore wall of parent material, while the bright region represents the pores of MOR. After impregnation was done, dark particles representing the agglomeration of added metal were appeared in the pore of MOR. This finding confirms that the metals are successfully impregnated. The nature of metal particles in the support material is also observed in TEM image. As shown in Fig. 6(b), Co, which formed smaller size agglomerates, would be deposited inside the pore of MOR, leading to the decrease of surface area as mentioned in Table 1. On the other hand, as shown in Fig. 6(c), Pd formed larger size agglomerates that it may not fit the pore provided by MOR, causing some of its particles to be deposited outside of the material pore instead. The Pd metal aggregation on the surface of MOR would add to its roughness which contributes to the increase of surface area as stated in Table 1.

\section{Hydrotreatment of CNSL}

The activities of the MOR, Co(1)/MOR, $\mathrm{Co}(2) /$ MOR, $\mathrm{Co}(3) / \mathrm{MOR}$ and $\mathrm{Pd} / \mathrm{MOR}$ were evaluated in the hydrotreatment of Cashew Nut Shell Liquid (CNSL). The results of each activity are shown in Table 3, the products are divided into 3 phases containing liquid fraction, gas fraction, and coke. Thermal hydrotreatment was revealed to exhibit the lowest production of liquid products with only a $40.01 \%$ conversion. The use of catalyst was shown to improve the liquid product consistently. The liquid product using non-loaded MOR catalyst was $49.64 \mathrm{wt} . \%$ and it gradually increased with the addition of metal to the support. The use of $\mathrm{Co}(1) / \mathrm{MOR}, \mathrm{Co}(2) / \mathrm{MOR}, \mathrm{Co}(3) / \mathrm{MOR}$ was shown to exhibit 58.9, 60.5 and 61.8 wt.\% conversion, respectively. The result implies that the conversion value increases with more metal particles present in the catalyst. This is

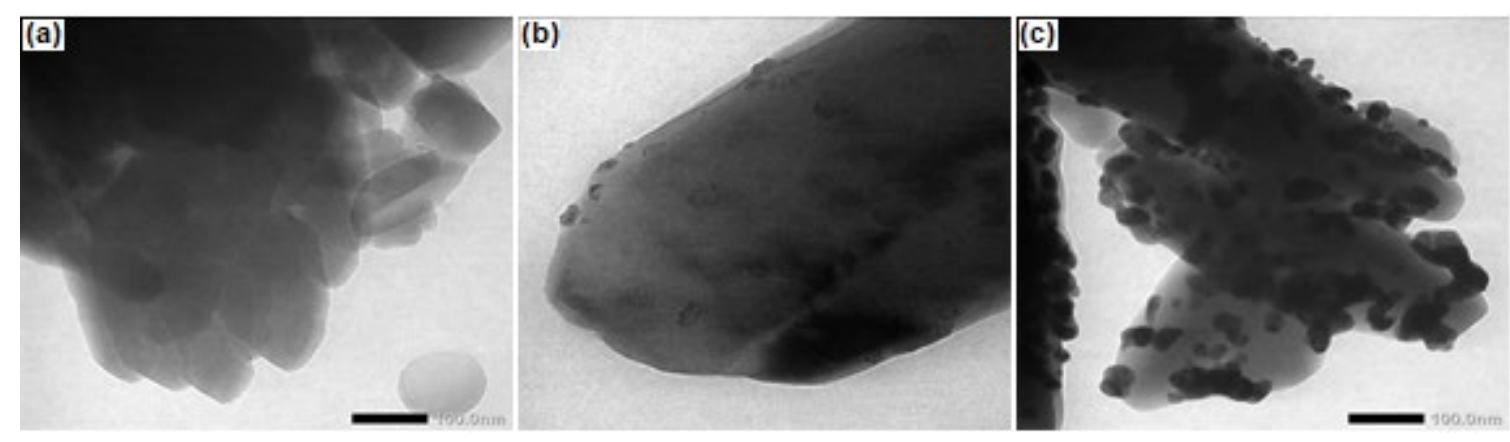

Fig 6. TEM images of (a) mordenite, (b) $\mathrm{Co}(3) / \mathrm{MOR}$, and (c) Pd/MOR 
Table 3. Product distribution hydrotreating of the CNSL

\begin{tabular}{lccccc}
\hline \multirow{2}{*}{ Catalyst } & \multicolumn{3}{c}{ Conversion (wt.\%) } & Residue & $\begin{array}{c}\text { Total conversion } \\
\text { (wt.\%) }\end{array}$ \\
\cline { 2 - 4 } & Liquid & Gas & Coke & & 87.69 \\
Thermal & 40.01 & 59.99 & 0 & 12.30 & 85.21 \\
MOR & 49.64 & 42.91 & 7.44 & 14.78 & 95.00 \\
Co(1)/MOR & 58.9 & 38.16 & 2.94 & 4.99 & 97.47 \\
Co(2)/MOR & 60.5 & 32.6 & 6.84 & 2.52 & 98.04 \\
Co(3)/MOR & 61.8 & 36.89 & 1.26 & 1.95 & 97.02 \\
Pd/MOR & 58.55 & 41.4 & 0.41 & 2.97 & \\
\hline
\end{tabular}

because metal particles provide empty $p$ orbital that can act and add more acid sites to the catalyst, as referred to the total acidity value data shown in Table 1 . These sites facilitate cracking mechanisms during hydrotreatment which leads to the production of more liquid products. Hydrotreating of CNSL oil using natural zeolite was done previously producing over $31.08 \mathrm{wt} . \%$ conversion [11]. $\mathrm{Co} / \mathrm{MOR}$ and $\mathrm{Pd} / \mathrm{MOR}$ catalysts give the better result of the conversion. The correlation between acidity value and conversion level is illustrated in Fig. 7.

We also compared the activity of $\mathrm{Pd}$ as noble metal with Co. In this study, it was revealed that $6 \%$ Co-loaded MOR (Co(3)/MOR) was able to exhibit higher liquid conversion than $0.5 \%$ Pd-loaded MOR (Pd/MOR). The result indicates the possibility to use Co as a noble metal substitute. Although the quantity of Co metal required for the optimum result was higher compared to $\mathrm{Pd}$, it was compensated with the high availability and lower price. Due to its characteristics as a noble metal, the small amount of Pd produce more liquid products. Moreover, Pd remains in metallic state much longer and can preserve its role as catalyst during the hydrotreatment process. A strong correlation between metal content, acidity and total conversion was observed in $\mathrm{Co} / \mathrm{MOR}$ catalyst. At the higher concentrations of metals, the acidity of the catalyst will increase, resulting in an increase of total conversion.

TEM images of Co(3)/MOR before and after the hydrotreatment process were shown in Fig. 8 . The picture showed coke deposition after the catalytic performance as indicated by the darker shade in Fig. 8(b). However, as reported in Table 1, Co(3)/MOR produced the least coke formation compared to the other Co-loaded MOR studied in this work. It shows that the catalyst exhibits good stability towards coke deposition. It was expected that $\mathrm{Co}(3) / \mathrm{MOR}$ may have longer lifetime. Table 4 listed all compounds found in the liquid products obtained from this work. Pd/MOR catalyst exhibits the highest selectivity for gasoline fraction, followed by $\mathrm{Co}(3) / \mathrm{MOR}$, $\mathrm{Co}(2) / \mathrm{MOR}, \mathrm{Co}(1) / \mathrm{MOR}, \mathrm{MOR}$, and thermal, respectively. Gasoline compounds were shown to be predominantly produced compared to the other compounds. This is correlated to the small size of gasoline

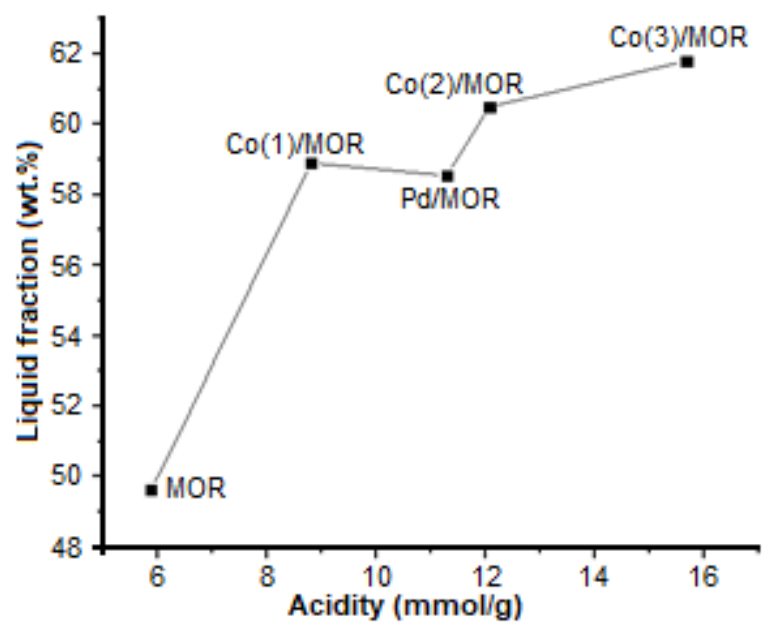

Fig 7. Correlation curve of liquid fraction product versus catalyst acidity

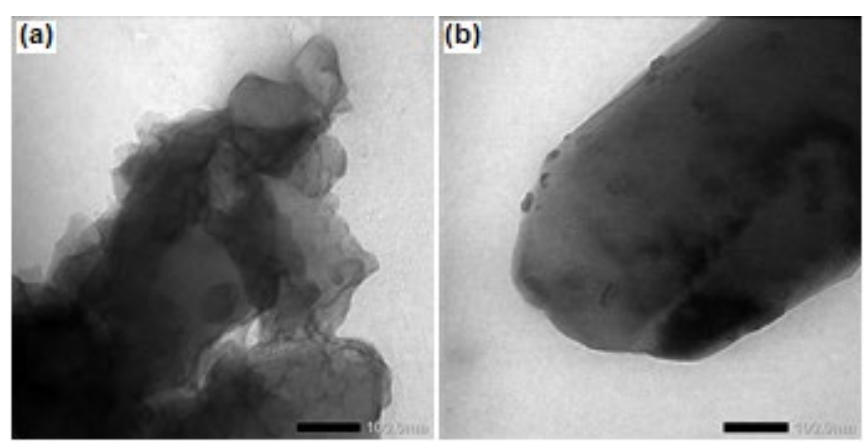

Fig 8. TEM images of Co(3)/MOR: (a) before, and (b) after hydrotreating 
Table 4. Distribution of compound in liquid product

\begin{tabular}{lccccc}
\hline \multirow{2}{*}{ Catalyst } & \multicolumn{5}{c}{ The compound in the liquid product } \\
\cline { 2 - 6 } & $\mathrm{C}_{5}-\mathrm{C}_{12}$ & $\mathrm{C}_{13}-\mathrm{C}_{17}$ & $\mathrm{C}>18$ & Alcohols & Organics \\
\hline Thermal & 13.67 & 11.18 & 1.44 & 11.48 & 2.24 \\
MOR & 16.53 & 15.60 & 0.89 & 12.84 & 3.78 \\
$\mathrm{Co}(1) / \mathrm{MOR}$ & 16.34 & 6.18 & 0.00 & 19.36 & 17.05 \\
$\mathrm{Co}(2) / \mathrm{MOR}$ & 23.47 & 7.55 & 0.00 & 20.55 & 9.01 \\
$\mathrm{Co}(3) / \mathrm{MOR}$ & 25.21 & 10.48 & 0.00 & 19.18 & 6.96 \\
$\mathrm{Pd} / \mathrm{MOR}$ & 34.50 & 0.50 & 0.00 & 13.88 & 9.68 \\
\hline
\end{tabular}

compound which contributes to its accessibility in entering and leaving the pore of MOR.

\section{- CONCLUSION}

The preparation of catalysts via the wetimpregnation method was successfully applied for $\mathrm{Co} / \mathrm{MOR}$ and $\mathrm{Pd} / \mathrm{MOR}$ catalysts. Each catalyst exhibited good activity in converting CNSL oil into fuel compounds. The characterization result showed that metal addition to MOR does not alter the crystallinity and morphology of the support material. The catalytic activity in producing liquid fraction showed a decrease with the sequence of $\mathrm{Co}(3) / \mathrm{MOR}>\mathrm{Co}(2) / \mathrm{MOR}>\mathrm{Pd} / \mathrm{MOR}>\mathrm{Co}(1) / \mathrm{MOR}>$ MOR. The highest liquid fraction was produced by Co(3)/MOR was 61.8 wt. $\%$ at $450{ }^{\circ} \mathrm{C}$.

\section{- ACKNOWLEDGMENTS}

The authors thank Universitas Gadjah Mada for financial support of this work under the scheme of RTA 2019 (Contract no.: 3188/UNI/DITLIT/DIT-LIT/LT/2019).

\section{- REFERENCES}

[1] Kumari, A.S., Penchalayya, Ch., Raju, A.V.S.R., and Kumar, P.R., 2011, Experimental investigations of IC engine with Pongamia diesel blends, IJAET, 2 (4), 54-58.

[2] Ong, H.C., Masjuki, H.H., Mahlia, T.M.I., Silitonga, A.S., Chong, W.T., and Talal, Y., 2014, Engine performance and emissions using Jathropha curcas, Ceiba pentrada and Calophyllum inophyllum bioduesel in a CI diesel engine, Energy, 69, 427-445.

[3] Astuti, R.B., Suyati, L., and Nuryanto, R., 2012, Pirolisis kulit biji jambu mete (cashew nut shell) dengan katalis Ag/zeolit, JKSA, 15 (3), 100-104.
[4] Listyati, D., and Sujarmoko, B., 2011, Nilai tambah ekonomi pengolahan jambu mete Indonesia, Buletin RISTRI, 2 (2), 231-238.

[5] Idah, P.A., Simeon, M.I., and Mohammed, M.A., 2014, Extraction and characterization of cashew nut (Anacardium occidentale) oil and cashew shell liquid oil, Acad. Res. Int., 5 (3), 50-54.

[6] Prasada, R., 2014, A review on CNSL biodiesel as an alternative fuel for diesel engine, IJSR, 3 (7), 20282038.

[7] Ciciszwili, G.W., Andronikaszwili, T.G., Kirov, G.N., and Filizowa, L.D., 1990, Zeolity Naturalne, Wydawnictwa Naukowo-Techniczne, Warszawa.

[8] Pastvova, J., Kaucky, D., Moravkova, J., Rathousky, J., Sklenak, S., Vorovkhta, M., Brabec, L., Pilar, R., Jakubec, I., Tabor, E., Klein, P., and Sazama, P., 2017, Effect of enhanced accessibility of acid sites in micromesoporous mordenite zeolites on hydroisomerization of $n$-hexane, ACS Catal., 7 (9), 5781-5795.

[9] Shi, J., Wang, Y., Yang, W., Tang, Y., and Xie, Z., 2015 , Recent advances of pore system construction in zeolite-catalyzed chemical industry processes, Chem. Soc. Rev., 44 (24), 8877-8903.

[10] Trisunaryanti, W., Triyono, Rizki, C.N., Saptoadi, H., Alimuddin, Z., Syamsiro, M., and Yoshikawa, K., 2013, Characteristics of metal supported-zeolite catalysts for hydrocracking of polyethylene terephtalat, IOSR-JAC, 3 (4), 29-34.

[11] Santi, D., and Efiyanti, L., 2014, Hidrorengkah minyak laka menggunakan katalis $\mathrm{NiO}$ /zeolit alam aktif dan $\mathrm{NiOMoO}$ /zeolit alam aktif menjadi fraksi berpotensi energi, JPHH, 32 (2), 93-102.

[12] Trisunaryanti, W., Triyono, T., Armunanto, R., 
Hastuti, L.P., Ristiana, D.D., and Ginting, R.V., 2018, Hydrocracking of a-cellulose using $\mathrm{Co}, \mathrm{Ni}$, and $\mathrm{Pd}$ supported on mordenite catalysts, Indones. J. Chem., 18 (1), 166-172.

[13] Triyono, Trisunaryanti, W., Ristiana, D.D., and Hastuti, L.P., 2019, Kinetic study of a-cellulose hydrocracking using $\mathrm{Ni}$ and $\mathrm{Pd}$ supported on mordenite catalysts, Orient. J. Chem., 35 (2), 643-647.

[14] Inoue, M., and Hiraswa, I., 2013, The relationship between crystal morphology and XRD peak intensity on $\mathrm{CaSO}_{4} \cdot 2 \mathrm{H}_{2} \mathrm{O}$, J. Cryst. Growth, 380, 169-175.

[15] Trisunaryanti, W., Syoufian, A., and Purwono, S., 2013, Characterization and modification of Indonesian natural zeolite for hydrocracking of waste lubricant oil into liquid fuel fraction, J. Chem. Chem. Eng., 7 (2), 175-180.

[16] Lu, M., Liu, X., Li, Y., Nie, Y., Lu, X., and Deng, D., 2016, Hydrocracking of bio-alkanes over Pt/AlMCM-41 mesoporous molecular sieves for bio-jet fuel production, J. Renewable Sustainable Energy, 8, 053103.

[17] Abdullah, Triyono, Trisunaryanti, W., and Haryadi, W., 2013, The optimum reaction time, activation energy and frequency factor of methyl ricinoleate nitration, Indones. J. Chem., 13 (1), 36-40.

[18] Xu, Y., Suzuki, Y., and Zhang, Z.G., 2013, Comparison of the activity stabilities of nanosized and microsized zeolites based Fe-Mo/HZSM- 5 catalysts in the non-oxidative $\mathrm{CH}_{4}$ dehydroaromatization under periodic $\mathrm{CH}_{4}-\mathrm{H}_{2}$ switching operation at 1073 K, Appl. Catal., A, 452, 105-116.

[19] Masiero, S.S., Marcilio, N.R., and Perez-Lopez, O.W., 2009, Aromatization of methane over MoFe/ZSM-5 catalysts, Catal. Lett., 131, 194-202.

[20] Nishi, Y., and Inagaki, M., 2016, "Gas adsorption/desorption isotherm for pore structure characterization" in Materials Science and Engineering of Carbon: Characterization, Eds. Inagaki, M., and Kang, F., Butterworth-Heinemann, Oxford, UK, 227-247.

[21] Trisunaryanti, W., Suarsih, E., Triyono, and Falah, I.I., 2019, Well-dispersed nickel nanoparticles on the external and internal surfaces of SBA-15 for hydrocracking of pyrolyzed a-cellulose, RSC $A d v$., 9 (3), 1230-1237.

[22] Gregg, S.J., and Sing, K.S.W., 1982, Adsorption, Surface Area, and Porosity, $2^{\text {nd }}$ Ed., Academic Press, London.

[23] Kostyniuk, A., Key, D., and Mdleleni, M., 2019, Effect of Fe-Mo promoters on HZSM-5 zeolite catalyst for 1-hexane aromatization, J. Saudi Chem. Soc., 23 (5), 612-626. 